\title{
Comparison of Process Control Viruses for use in Extraction and Detection of Human Norovirus from Food Matrices
}

Jennifer Gentry-Shields*æ and Lee-Ann Jaykus

Department of Food, Bioprocessing and Nutrition Sciences, North Carolina State University, Raleigh, NC 27695

*Corresponding Author

Email: $\quad$ shields.jg@pg.com

Phone: $\quad$ (513) 622-0718

Address: $\quad 8700$ Mason-Montgomery Road, Mason OH 45040

¥Present address: Global Microbiology Capability Organization, Procter \& Gamble, Mason, $\mathrm{OH} 45040$ 


\section{Abstract}

2 Although RT-qPCR is a powerful tool for human norovirus (HuNoV) detection, low virus

3 concentrations in potentially large sample volumes necessitate the use of inefficient sample

4 processing step(s) prior to detection. Process control viruses (PCVs) are used to monitor

5 the efficiency of these virus concentration steps. This study compared five PCVs

6 [Mengovirus (Mengo), murine norovirus (MNV-1), MS2 coliphage, Tulane virus, and turnip

7 crinkle virus (TCV)] to two HuNoV strains for recovery during the steps of elution,

8 polyethylene glycol precipitation (PEG), and RNA extraction from select foods (lettuce and

9 sliced deli ham). Results demonstrate high recovery efficiencies of HuNoV GI.6 and GII.4

10 using the methods described in this study: combined (sequential) losses during processing

11 from sliced deli ham and lettuce were $<1 \log _{10}$ genome equivalent copies (GEC). When

12 considering the processing steps separately, HuNoV loss was negligible after elution, and

13 low after PEG precipitation (mean $0.5 \log _{10}$ GEC) and RNA extraction (mean $0.1 \log _{10}$ GEC).

14 The virus that least mimicked the behavior of HuNoV during sample processing was MNV-

15 1. Of the viruses tested, a commercial mengovirus strain gave recovery efficiencies closest

16 to HuNoV, showing combined losses from sliced deli ham and lettuce of $<1 \log _{10}$ GEC and

$17 \sim 1 \log _{10}$ GEC, respectively. All PCVs do not behave equivalently and validation of their

18 performance is recommended before their routine use on an application-by-application

19 basis.

20

21 Keywords: norovirus, process control virus, RT-qPCR, processing efficiency

Abbreviations: HuNoV, human norovirus; PCV, process control virus; MNV-1, murine norovirus; TCV, turnip crinkle virus; PEG, polyethylene glycol; GEC, genome equivalent copies; RT, room temperature; RT-qPCR, real-time quantitative polymerase chain reaction; 
BSA, bovine serum albumin; TCID50, median tissue culture infectious dose; CPE, cytopathic effect; PBS, phosphate buffered saline; FBS, fetal bovine serum. 


\section{1. Introduction}

23 Human noroviruses (HuNoV) are the leading cause of foodborne disease in the

24 United States (Scallan et al., 2011) and perhaps worldwide (Glass, Parashar, \& Estes, 2009).

25 Despite their public health significance, routine detection of HuNoV in food and

26 environmental samples has been historically difficult to quantify, in part due to the

27 potentially low densities of the virus in foods and the lack of a cell culture system.

28 Molecular amplification methods, specifically reverse transcription quantitative PCR (RT-

29 qPCR), offer powerful tools for rapid detection of HuNoV in complex matrices. In addition

30 to avoiding the need for cultivation, RT-qPCR can save both time and expenses and has the

31 potential to be sensitive, inexpensive, quantitative, and amenable to automation. However,

32 low virus concentrations in potentially large sample volumes necessitates the use of labor

33 intensive and potentially inefficient concentration step(s) prior to detection (Knight, Li,

34 Uyttendaele, \& Jaykus, 2013). Loss during these processing procedures can result in an

35 underestimation of HuNoV load or false negative results.

36 To ensure accurate quantitation and interpretation of molecular data for HuNoV in

37 various food matrices, controls are needed to determine the efficiency of various

38 processing steps, including virus recovery, concentration, RNA extraction, and RT-PCR.

39 Nucleic acid controls have been developed to quantify the RT-qPCR efficiency of HuNoV

40 (Gregory, Webster, Griffith, \& Stewart, 2011; Hata et al., 2011; Lee et al., 2011; Liu et al.,

41 2013; Stals et al., 2009), as well as to quantify the recovery efficiency of viral nucleic acid

42 during extraction procedures (da Silva et al., 2007; Hata et al., 2011; Mormann, Dabisch, \&

43 Becker, 2010). A few studies have attempted to quantify the recovery efficiencies of

44 concentration procedures utilizing process control viruses (PCVs). For example, 
45 mengovirus has been utilized as a PCV for HuNoV in wastewater (da Silva et al., 2007) and 46 in shellfish (Le Guyader et al., 2009), and MS2 has been used to monitor recovery of HuNoV 47 from experimentally contaminated foods (Mormann et al., 2010). However, at present, 48 there are no published studies evaluating potential PCVs for their similarity to HuNoV 49 during processing; yet proven controls are imperative for enhancing the detection and 50 accurate quantitation of HuNoV from complex sample matrices.

51 An ideal PCV for HuNoV would be similar morphologically and physiochemically to $52 \mathrm{HuNoV}$, i.e. a non-enveloped positive-sense, single stranded RNA virus; sufficiently 53 genetically distinct from HuNoV; and not normally expected to occur naturally in the 54 foodstuffs being analyzed ("Microbiology of food and animal feed - Horizontal method for 55 determination of hepatitis A virus and norovirus in food using real-time RT-PCR - Part 1: 56 Method for quantification," 2013). Unfortunately, no one PCV is ideal. The goal of this 57 study was to evaluate five viruses for use as PCVs when recovering and detecting HuNoV in 58 foods: Mengovirus (Mengo), murine norovirus (MNV-1), MS2 coliphage, Tulane virus, and 59 turnip crinkle virus (TCV). All viruses are icosahedral, non-enveloped, positive-sense 60 single-stranded RNA viruses with similar size, genome, and isoelectric point to HuNoV 61 (Table 1). Mengo is a member of the Picorniviridae family and a commonly used PCV (da 62 Silva et al., 2007; Le Guyader et al., 2009). MS2 is a virus in the family Leviviridae that 63 infects the bacterium Escherichia coli and other members of the Enterobacteriaceae. MNV-1 64 and Tulane are culturable HuNoV surrogates in the family Caliciviridae utilized in HuNoV 65 inactivation and persistence studies (Cromeans et al., 2014), and MNV-1 has been used as a 66 PCV for hepatitis A virus (Coudray, Merle, Martin-Latil, Guillier, \& Perelle, 2013; Martin67 Latil, Hennechart-Collette, Guillier, \& Perelle, 2012). TCV is a plant pathogen in the family 
68 Tombusviridae first isolated from turnip and limited in spread to the UK and Yugoslavia

69 (http://www.dpvweb.net/dpv/showdpv.php?dpvno=109). These potential PCVs were

70 evaluated against HuNoV GI.6, a commonly implicated foodborne outbreak strain, and

71 GII.4, the most common cause of HuNoV outbreaks, during virus recovery (elution),

72 concentration, and RNA extraction procedures commonly used for foods (Baert,

73 Uyttendaele, \& Debevere, 2008; Fraisse et al., 2011; "Microbiology of food and animal feed -

74 Horizontal method for determination of hepatitis A virus and norovirus in food using real-

75 time RT-PCR - Part 1: Method for quantification," 2013; Park, Kim, \& Ko, 2010; Summa,

76 Bonsdorff, \& Maunula, 2012).

78 2. Methods

792.1 Viruses and virus propagation

80 HuNoV strains GI.6 and GII.4 were obtained as clinical stool specimens from HuNoV 81 outbreaks (provided by S. R. Greene NCPH, Raleigh, NC). Stool samples were suspended $8220 \%$ in phosphate buffered saline (PBS, pH 7.4) and estimated to have a threshold cycle 83 (CT) of 25 and 21, respectively (personal communication, S. R. Green), equivalent to a titer 84 of $7.8 \times 10^{7}$ (GI.6) and $2.7 \times 10^{7}$ (GII.4) genome equivalent copies (GEC)/ml by RT-qPCR 85 (Section 2.3.1).

86 Mengovirus strain $\mathrm{MC}_{0}$, an avirulent strain lacking the poly $(\mathrm{C})$ tract, was purchased 87 from American Type Culture Collection (ATCC VR-1597) with a concentration of $6.2 \times 10^{8}$ $88 \mathrm{PFU} / \mathrm{ml}$. Due to a shortage by the manufacturer, additional mengo was obtained as a part of 89 an RNA extraction control kit (developed and manufactured by CEERAM SAS and 90 distributed by Life Technologies ${ }^{\mathrm{TM}}$ ) with a concentration of $1.6 \times 10^{8} \mathrm{GEC} / \mathrm{ml}$. 
MS2 coliphage (ATCC 15597-B1) was purchased from ATCC (Manassas, VA). The

92 virus stock was quantified using the Single Agar Layer method 1602 (USEPA, 2001) using

93 Escherichia coli F+ cells purchased from ATCC (15597) and cultured in trypic soy broth

94 (Fisher Scientific, Waltham, MA). Stock titer used in experiments was 7.7x107 PFU/ml.

95 MNV-1 was obtained from the laboratory of Dr. Howard Virgin, (Washington

96 University, St. Louis, MO). The virus stock was propagated in RAW 264.7 cells, a mouse

97 monocyte macrophage line purchased from ATCC (TIB-71), and the cells were cultured in

98 high-glucose Dulbecco's modified Eagle medium (DMEM, Life Technologies, Carlsbad, CA)

99 supplemented with 10\% low endotoxin fetal bovine serum (FBS, HyClone, Logan, UT) at

$10037^{\circ} \mathrm{C}$ under a $5 \% \mathrm{CO}_{2}$ atmosphere as described previously (Tung, Macinga, Arbogast, \&

101 Jaykus, 2013). MNV-1 stock titers were $1.3 \times 10^{6} \mathrm{PFU} / \mathrm{ml}$.

102 A purified stock of TCV was obtained from the laboratory of Dr. Steve Lommel

103 (North Carolina State University, Raleigh, NC). Virus concentration was determined using 104 spectroscopy as described previously (Gentry-Shields \& Stewart, 2013) at 2.0x1015 virus 105 particles/ml.

106 Tulane virus was obtained from the laboratory of Dr. Jason Jiang (Cincinnati

107 Children's Hospital, Cincinnati, OH] and cultivated in LLC-MK2 cells (Farkas, Sestak, Wei, \& 108 Jiang, 2008), a rhesus monkey kidney epithelial line, that were purchased from ATCC (CCL109 7). The cells were cultured in M199 medium (Mediatech Inc., Manassas, VA) supplemented 110 with 10\% fetal bovine serum (FBS, Cambrex Bio Science Walkersville Inc., Walkersville, 
4114 NJ) until 90\% confluent ( $\sim 24$ h). Eluates were serially diluted $10^{-1}$ to $10^{-6}$ in M199 media.

7115 Each well (6 per dilution) was inoculated with $50 \mu$ l of diluted sample. The inoculated plates were incubated at $37^{\circ} \mathrm{C}$ in $5 \% \mathrm{CO}_{2}$ for $1 \mathrm{~h}$ with periodic rocking, followed by the addition of $1 \mathrm{ml}$ maintenance media (M199 media supplemented with 2\% FBS and 1\% Pen118 strep). Starting $24 \mathrm{~h}$ after inoculation, the wells were visually examined for cytopathic 119 effect (CPE) using an inverted microscope (Nikon Inc. Melville, NY). CPE was generally fully 120 developed $5 \mathrm{~d}$ post-inoculation. The stock titer was calculated using the Reed-Muench 121 Calculator Spreadsheet

122 (http://www.med.yale.edu/micropath/pdf/infectivity\%20calculator.xls) to be $1.3 \times 10^{7}$ $\mathrm{TCID}_{50} / \mathrm{ml}$

124 The concentrations of all viruses in genome equivalent copies (GEC) were 125 determined as described previously (Gentry-Shields \& Stewart, 2013). All viruses were 126 stored at $-80^{\circ} \mathrm{C}$.

\section{$128 \quad 2.2$ Experimental Procedures}

129 All five potential PCVs were evaluated against HuNoV GI.6 and GII.4 for the steps of 131 below.

\section{2.2.1 Elution}

Fifteen g of romaine lettuce or $25 \mathrm{~g}$ of sliced deli ham were seeded with $20 \mu \mathrm{l}$ of each 135 from 7-10 $\log _{10} \mathrm{GEC}$ ) and dried for $30 \mathrm{~min}$ at room temperature (RT). The virus-seeded 136 food sample was placed in a polypropylene bag containing a filter compartment (Nasco 
Whirl-Pak, Fort Atkinson, WI) and soaked with $25 \mathrm{ml}$ elution buffer (0.04M glycine, 0.15M $\mathrm{NaCl}, 0.01 \mathrm{M} \mathrm{NaOH}$ [all from Fisher Scientific], $\mathrm{pH}$ 9.0). The sample was stomached for $1 \mathrm{~min}$ at $230 \mathrm{rpm}$ using a stomacher (Seward, Davie, FL). The rinse fluid was removed via the filter compartment of the bag to a $50-\mathrm{ml}$ centrifuge tube and adjusted to $\mathrm{pH} 7.0 \pm 0.5$ with $1410.1 \mathrm{M} \mathrm{HCl}$. To quantify virus recovery during elution, un-inoculated samples were processed in the same manner as above then this set of control samples was inoculated with the same quantity of virus after the elution step. All samples were stored at $-20^{\circ} \mathrm{C}$ before polyethylene glycol (PEG) precipitation and chloroform:butanol purification, RNA extraction, and RT-qPCR (described below). Elution recovery was quantified as the difference in virus quantity detected by RT-qPCR from samples spiked pre-elution to samples spiked post-elution. For each virus spike concentration, experiments were performed in triplicate with three independent samples processed per replicate.

\subsubsection{Concentration}

Viruses were concentrated from lettuce and ham eluates using polyethylene glycol (PEG) precipitation. Twenty-five ml "mock" eluates obtained from un-inoculated foods were seeded with $50 \mu \mathrm{l}$ of each virus (total inoculum concentration ranging from $5-10 \log _{10}$ 154 GEC), and subjected to precipitation by the addition of PEG MW 8000 (Sigma-Aldrich, 155 Steinheim, Germany), NaCl, and bovine serum albumin (BSA, Fisher Scientific) in a final 156 concentration of $12 \%(\mathrm{w} / \mathrm{v}), 5 \%$, and 3\%, respectively (Liu et al., 2013). Samples were 157 incubated on a shaking platform at $4^{\circ} \mathrm{C}$ for $15 \mathrm{~min}$ or $2 \mathrm{~h}$ and centrifuged at $18,500 \times \mathrm{g}$ for $15820 \mathrm{~min}$ at $4^{\circ} \mathrm{C}$. The pellet was suspended in $1 \mathrm{ml}$ of $\mathrm{PBS}$ and stored at $-20^{\circ} \mathrm{C}$. To remove residual inhibitory substances, the virus concentrates were further subjected to a 


\subsubsection{RNA Extraction}

One ml of PBS was seeded with $100 \mu \mathrm{l}$ of each virus (total concentration ranging 171 from 2-8 $\log _{10}$ GEC) and nucleic acid extraction was performed using the automated

172 NucliSENS® easyMag® system (bioMérieux, Durham, NC) as per manufacturer 173 instructions. The final purified RNA was eluted into $40 \mu \mathrm{l}$ of proprietary buffer. RNA

174 extracts were stored at $-80^{\circ} \mathrm{C}$ until analysis by RT-qPCR. Viral recovery during RNA

175 extraction was estimated by comparing virus quantity pre-RNA extraction to that post-

177 with three independent samples processed per replicate.

\subsection{Quantification of virus recovery}

\subsubsection{RT-qPCR}

RNA isolations were diluted 1:10 and 1:100, and all three dilutions were subjected to RT-qPCR amplification in duplicate using primers described in Table 2 . The $25 \mu$ RT- 
qPCR mixture consisted of $2.5 \mu \mathrm{l}$ of RNA, $400 \mathrm{nM}$ of forward and reverse primers, $200 \mathrm{nM}$ of fluorescently labeled TaqMan probe, $12.5 \mu \mathrm{l} 2 \times$ reaction buffer (SuperScript ${ }^{\circledR}$ III OneStep qRT-PCR Kit, Invitrogen, Grand Island, NY), and $0.5 \mu$ RT/Platinum® Taq Mix. The reaction mixture was subjected to a one-step thermal cycling profile using a CFX96 Touch $^{\text {TM }}$ Real Time PCR Detection System (Bio-Rad, Hercules, CA) under the following amplification conditions: (i) reverse transcription for $30 \mathrm{~min}$ at $50^{\circ} \mathrm{C}$; (ii) initial denaturation for $15 \mathrm{~min}$ at $95^{\circ} \mathrm{C}$; and (iii) 45 cycles of $15 \mathrm{~s}$ at $95^{\circ} \mathrm{C}$ and $30 \mathrm{~s}$ at $60^{\circ} \mathrm{C}$.

Virus concentration ( $\log _{10} \mathrm{GEC}$ ) was estimated by comparison with standard curves

191 for each virus generated using RNA transcripts serially diluted 1:10 in DEPC-treated water 192 and subjected to RT-qPCR in triplicate. The $\log _{10}$-transformed RNA GEC was plotted against 193 the CT value and analyzed by linear regression to make the standard curves. RT-qPCR 194 assays were repeated 3 times over non-consecutive days and combined to create one 195 standard curve.

2.3.2 Cell Culture

Recovery of MNV-1, MS2, and Tulane virus after elution and concentration was also quantified by cell culture using the methods described in Section 2.1.

\subsection{Statistical Analyses}

All statistical analyses were performed using JMP Pro 11 (SAS Institute Inc., Cary, NC). The Shapiro-Wilk test found that virus losses were not normally distributed (data not shown) so all statistical tests were non-parametric. The impact of initial spike concentration on virus recovery was evaluated using the Kruskal-Wallis test for significance. Losses experienced by each virus during RNA extraction, PEG precipitation, 
and elution (expressed as $\log _{10} \mathrm{GEC}, \mathrm{PFU}$, or TCID 50 ) were also compared using the

Kruskal-Wallis test and followed by the Steel-Dwass with control test to compare

individual virus losses to HuNoV GI.6 and GII.4. All tests were conducted with $\alpha=0.05$, and associations with a $\mathrm{p}<0.05$ were considered significant.

\section{Results}

3.1 Elution

All virus losses were $<1 \log _{10}$ GEC (Figure 1) during elution, regardless of initial spike concentration. All PCVs had statistically similar recoveries to HuNoV GI.6 and GII.4 from both lettuce and sliced deli ham $(\mathrm{p}>0.05)$.

\subsection{Concentration}

Mean HuNoV losses during concentration from sliced deli ham were $0.6 \pm 0.8$ and $0.4 \pm 0.6$ GEC for GI.6 and GII.4, respectively, and losses from lettuce were $0.5 \pm 0.8$ and 0.7 \pm 1.3 GEC, respectively. All PCVs had statistically similar recoveries to HuNoV GI.6 and GII.4 in both lettuce and ham ( $p>0.05$, Figure 2). The recovery efficiency was not statistically different when varying the PEG precipitation incubation period from $2 \mathrm{~h}$ to 15 min or when varying the initial spike concentration of virus $(\mathrm{p}>0.05)$.

\subsection{RNA Extraction}

Viral RNA extraction efficiencies varied widely by virus type and by initial spike 227 concentration ( $\mathrm{p}<0.05$, Figure 3). HuNoV GI.6 and GII.4 experienced low losses during RNA extraction, $<1 \log _{10}$ GEC across all initial spike concentrations evaluated. No PCV had a 
statistically similar recovery to HuNoV GI.6 or GII.4 at medium (4-5.9 $\log _{10}$ GEC) and high (6-7.9 $\log _{10}$ GEC) inoculum levels. At a low inoculum level (2-3.9 $\left.\log _{10} \mathrm{GEC}\right)$, TCV and

Tulane virus had statistically similar recoveries to both HuNoV GI.6 and GII.4 ( $\mathrm{p}>0.05)$, while Mengo (Ceeram) had a statistically similar recovery to HuNoV GI.6.

\subsection{Cell Culture}

MNV-1, MS2, and Tulane virus losses occurring during elution and concentration steps were quantified by cell culture in addition to RT-qPCR. MS2 losses during both elution and PEG precipitation were similar when quantified by infectivity assays or by RTqPCR (Table 3). Similarly, MNV-1 losses during PEG precipitation were similar when quantified by infectivity assays or by RT-qPCR (MNV-1 could not be detected by cell culture after elution experiments). However, Tulane losses quantified by TCID 50 assays were much higher than losses quantified by RT-qPCR for elution from lettuce (loss of $3.2 \pm 0.2 \log _{10}$ $\left.\mathrm{TCID}_{50} / \mathrm{ml}\right)$ and PEG precipitation from sliced deli ham $\left(2.7 \pm 0.7 \log _{10} \mathrm{TCID}_{50} / \mathrm{ml}\right)$.

244 4. Discussion

Since the concept of PCVs was posed almost a decade ago, various viruses have been used to serve this role (e.g., da Silva et al., 2007; Le Guyader et al., 2009). However, in most cases high titers of PCVs are spiked into the food to be processed for virus concentration and purification, with little knowledge of how efficiently those PCVs are being recovered. Nonetheless, the use of a validated PCV is a requirement for detection of $\mathrm{HuNoV}$ in food matrices ("Microbiology of food and animal feed - Horizontal method for determination of hepatitis A virus and norovirus in food using real-time RT-PCR - Part 1: Method for 
quantification," 2013). To our knowledge, this is the first study of its kind in which head-tohead comparisons of PCVs were made for the steps of elution, concentration, and RNA extraction as applied to recovery of HuNoV in select foods.

High recovery efficiencies were observed for both HuNoV strains tested using the sample processing methods. Specifically, losses were negligible during elution, averaged $0.5 \log _{10}$ GEC for the concentration step, and averaged $0.1 \log _{10}$ GEC for RNA extraction. Combined, this equates to about a $1 \log _{10}$ GEC loss in recovery of HuNoV using this particular virus extraction/detection protocol, with little difference between GI.6 and GII.4 strains or spike level. These recovery efficiencies are similar to those reported by others using similar methods (Baert et al., 2008; Griffin, Brinkman, Hedrick, Rhodes, \& Fout, 2014; Park et al., 2010; Summa et al., 2012). For example, Summa et al. (2012) reported recovery efficiencies of $19 \%$ and $47 \%$ from lettuce and ham (including elution and PEG precipitation). Park et al. (2010) reported elution recovery efficiencies of $65 \%$ and $40 \%$ from lettuce and ham using a similar elution buffer to this study.

When examining the separate steps of elution and concentration, most PCVs showed virtually no virus loss during elution and losses $<1.5 \log _{10}$ GEC for the concentration step, although some variability was observed with the latter. Comparatively speaking, losses during RNA extraction were higher than the previous two steps. RNA recoveries for the PCVs varied considerably, but in general they were similar to those reported in previous studies. Stals et al. (2011) reported recoveries of 1-12\% for HuNoV GI, GII, and MNV-1 using the easyMAG RNA purification system, and Costafreda et al. (2006) reported recoveries of 1.5-11.6\% for mengo and hepatitis E viruses using a Qiagen RNeasy kit. Inoculum level influenced RNA recovery for most viruses, including mengo, MS2, MNV-1, 
HuNoV GII.4, and Tulane. Variance associated with inoculum level has been demonstrated for this system previously; Stals et al. (2011) reported greater recovery with a higher inoculum level of HuNoV GI and GII vs. a lower inoculum level. Surprisingly, viral RNA recovery in our study waffled with initial spike concentration - HuNoV GII.4 RNA recovery decreased with higher inoculum levels while MS2 RNA recovery increased.

Keeping in mind the specific parameters of this study, we can conclude that, based on combined losses, the PCV with the most dissimilar recovery to HuNoV was MNV-1, with 2-3 $\log _{10}$ GEC combined losses from sliced deli ham and lettuce. In fact, MNV-1 losses were so high during RNA extraction $\left(2.0 \pm 0.5 \log _{10}\right.$ GEC) that MNV-1 could not be detected when low and medium spike volumes were used, and thus recovery could only be evaluated using an initial spike concentration $\geq 6 \log _{10}$ GEC. We suspect that the reason for this low recovery may be related to a high concentration of extra-viral RNA or a low ratio of infectious to noninfectious virus particles. This is supported by the difference in MNV-1 stock titer as evaluated by cell culture $\left(6.1 \log _{10}\right.$ PFU/ml) versus by RT-qPCR $\left(11.8 \log _{10}\right.$ $\mathrm{GEC} / \mathrm{ml}$ ). One way to avoid this problem in the future may be the use of an RNase pretreatment to digest free viral RNA and, theoretically, the RNA associated with non-intact capsids (Li et al., 2012; Topping et al., 2009).

Choosing a single PCV that most mimicked HuNoV during processing and detection is more difficult. Based on the combined recoveries in elution, concentration, and RNA extraction, MS2 and Tulane virus performed relatively well across all spike levels. As a bacteriophage, MS2 is easy to work with and can be produced at high concentration, but may have chemical and/or structural features that impact its usefulness for all applications ("Microbiology of food and animal feed - Horizontal method for determination of hepatitis 
A virus and norovirus in food using real-time RT-PCR - Part 1: Method for quantification," 2013). Tulane virus is closer to HuNoV structurally, but is difficult to obtain in high concentrations and is not yet widely used. Mengovirus (purchased as part of a kit from Life Technologies), with combined losses from sliced deli ham and lettuce of $<1 \log _{10}$ GEC and $\sim 1 \log _{10}$ GEC, respectively, is a good PVC candidate. In addition to its similar recovery to HuNoV during processing, an additional benefit to the use of Mengo is that it can be grown in vitro, allowing for in-house propagation, quantification, and purification. Interestingly, in our study we also evaluated a mengovirus suspension purchased from another source, which produced significantly lower RNA extraction efficiency (mean loss $=2.0 \pm 0.8 \log _{10}$ GEC) compared to the strain obtained from Life Technologies (mean loss $=0.6 \pm 0.4 \log _{10}$ GEC). While the reason for such a discrepancy is unknown, it is clear that differences in virus source can drastically impact the efficiency of RNA extraction, and perhaps other steps in virus concentration and purification schemes. These findings reiterate the importance of using high quality, standardized virus stocks as PCVs.

This study provides evidence of the virus recovery efficiencies for commonly used concentration and purification steps for HuNoV extraction from foods. For all PCVs, the combined steps of elution and PEG precipitation usually resulted in $<1.5 \log _{10}$ GEC losses, but RNA extraction losses were higher and more variable. This suggests that the efficiency of this latter step must be carefully considered when designing virus concentration and purification methods for foods. In fact, it appears that small adjustments in processing methods can have significant effects on virus recovery efficiency and reiterates the requirement for a PCV. While recovery efficiencies varied by virus and by processing step, most of the viruses evaluated would be suitable PCVs for monitoring the efficiency of 
321 HuNoV GI and GII extraction and detection using the methods described in this study.

7322 Consideration for choice of PCV may take into account availability of virus stocks,

9323 laboratory constraints (e.g., for cell culture), and food/environmental matrix to be 


\section{Figures}

Figure 1. Box and whisker plot depicting the losses of each virus (in $\log _{10} \mathrm{GEC}$ ) during elution from sliced deli ham and lettuce. The lower boundary of the box indicates the 25 th percentile, the line within the box represents the median, and the boundary of the box farthest from zero indicates the 75th percentile. Whiskers below and above the box indicate the 10th and 90th percentiles, respectively. All viruses were spiked onto triplicate samples and experiments were performed in triplicate using varying concentrations (7-10 $\log _{10}$ GEC) of virus. Input concentration of virus did not make a significant difference in recovery efficiency $(p>0.05)$ so box and whisker plots represent all spike concentrations of an individual virus.

344 Figure 2. Box and whisker plot depicting the losses of each virus (in $\log _{10}$ GEC) during PEG concentration from sliced deli ham and lettuce. The lower boundary of the box indicates the 25 th percentile, the line within the box represents the median, and the boundary of the box farthest from zero indicates the 75th percentile. Whiskers below and above the box indicate the 10th and 90th percentiles, respectively. All viruses were spiked into triplicate samples and experiments were performed in triplicate using varying concentrations of virus (5-10 $\log _{10} \mathrm{GEC}$ ). Input concentration of virus did not make a significant difference in recovery efficiency $(p>0.05)$ so box and whisker plots represent all spike concentrations of an individual virus.

354 Figure 3. Box and whisker plot depicting the losses experienced by each virus (in $\log _{10}$ GEC) 355 during RNA extraction. The lower boundary of the box indicates the 25th percentile, the 
${ }_{5}^{4} 356$ line within the box represents the median, and the boundary of the box farthest from zero

7357 indicates the 75th percentile. Whiskers below and above the box indicate the 10th and 90th

9358 percentiles, respectively, and points represent outliers. All viruses were spiked into 

7

8

364 Table 1. Human norovirus and potential process control virus size, genome length, and isoelectric point.

\begin{tabular}{llll}
\hline Virus & $\begin{array}{l}\text { Particle Size (nm. } \\
\text { diam.) }\end{array}$ & $\begin{array}{l}\text { Genome Length } \\
(\mathrm{kb})\end{array}$ & $\begin{array}{l}\text { Isoelectric point } \\
(\mathrm{pI})\end{array}$ \\
\hline $\begin{array}{l}\text { Human norovirus } \\
\text { (HuNoV) }\end{array}$ & $38-40$ & 7.6 & $5.5-6.0$ \\
$\begin{array}{l}\text { Mengovirus (Mengo) } \\
\text { Murine norovirus (MNV- }\end{array}$ & 30 & & \\
1) & $28-35$ & 8.4 & Unknown \\
MS2 coliphage & 27 & 7.4 & 4.8 \\
$\begin{array}{l}\text { Tulane virus } \\
\begin{array}{l}\text { Turnip crinkle virus } \\
\text { (TCV) }\end{array}\end{array}$ & 40 & 3.6 & 3.9 \\
\hline
\end{tabular}

(Human nor)

Mengovirus (Mengo) 30

Murine norovirus (MNV- $28-35$

MS2 coliphage

40

6.7

$5.0-6.0$

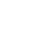


${ }_{5}^{4} 367$ Table 2. Primer and probe identities, sequences, oligo, and source for RT-qPCR assays used

\begin{tabular}{|c|c|c|c|c|}
\hline Virus & Name & Sequence (5'-3') & Location & Reference \\
\hline \multirow{4}{*}{$\begin{array}{l}\text { Norovirus } \\
\text { GI.6 (HuNoV } \\
\text { GI.6) }\end{array}$} & COG1F & CGYTGGATGCGNTTYCATGA & 5291 & \multirow{4}{*}{$\begin{array}{l}\text { (Kageyama et } \\
\text { al., 2003) }\end{array}$} \\
\hline & COG1R & CTTAGACGCCATCATCATTYAC & 5375 & \\
\hline & Ring1a & $\begin{array}{l}\text { 6-FAM-AGATYGCGATCYCCTGTCCA- } \\
\text { BHQ1 }\end{array}$ & 5340 & \\
\hline & Ring1b & $\begin{array}{l}\text { 6-FAM-AGATCGCGGTCTCCTGTCCA- } \\
\text { BHQ1 }\end{array}$ & 5340 & \\
\hline \multirow{3}{*}{$\begin{array}{l}\text { Norovirus } \\
\text { GII.4 } \\
\text { (HuNoV } \\
\text { GII.4) }\end{array}$} & JJV2F & CAAGAGTCAATGTTTAGGTGGATGAG & 5003 & \multirow{3}{*}{$\begin{array}{l}\text { (Jothikumar } \\
\text { et al., 2005) }\end{array}$} \\
\hline & COG2R & TCGACGCCATCTTCATTCACA & 5080 & \\
\hline & RING2P & $\begin{array}{l}\text { 6-FAM-TGGGAGGGCGATCGCAATCT- } \\
\text { BHQ1 }\end{array}$ & 5048 & \\
\hline \multirow{3}{*}{$\begin{array}{l}\text { Murine } \\
\text { norovirus-1 } \\
\text { (MNV-1) }\end{array}$} & G54763F & TGATCGTGCCAGCATCGA & 4763 & \multirow{3}{*}{$\begin{array}{l}\text { (Tung et al., } \\
\text { 2013) }\end{array}$} \\
\hline & G54863R & $\begin{array}{l}\text { GTTGGGAGGGTCTCTGAGCAT } \\
\text { 6-FAM- }\end{array}$ & 4884 & \\
\hline & G54808P & $\begin{array}{l}\text { CTACCCACCAGAACCCCTTTGAGACTC- } \\
\text { BHQ1 }\end{array}$ & 4808 & \\
\hline \multirow{3}{*}{$\begin{array}{l}\text { Turnip } \\
\text { crinkle virus } \\
\text { (TCV) }\end{array}$} & TCV900F & GTTCGACGCATCTTCCATATCT & 908 & \multirow{3}{*}{ This study } \\
\hline & TCV900R & $\begin{array}{l}\text { CTCTTTCСАТСААСССТСТТСТC } \\
\text { 6-FAM- }\end{array}$ & 1008 & \\
\hline & TCV900Probe & $\begin{array}{l}\text { TGGGCAATGGTTTAGACTTTGGAGTCC- } \\
\text { BHQ1 }\end{array}$ & 936 & \\
\hline \multirow{3}{*}{$\begin{array}{l}\text { Mengovirus } \\
\text { (Mengo) }\end{array}$} & Mengo 110 & GCGGGTCCTGCCGAAAGT & 110 & \multirow{3}{*}{$\begin{array}{l}\text { (Pintó, } \\
\text { Costafreda, \& } \\
\text { Bosch, 2009) }\end{array}$} \\
\hline & Mengo 209 & GAAGTAACATATAGACAGACGCACAC & 209 & \\
\hline & Mengo 147 & $\begin{array}{l}\text { 6-FAM-ATCACATTACTGGCCGAAGC- } \\
\text { BHQ1 }\end{array}$ & 147 & \\
\hline \multirow{3}{*}{$\begin{array}{l}\text { MS2 } \\
\text { coliphage }\end{array}$} & MS2qfor & ATTCCGACTGCGAGCTTATT & 1630 & \multirow{3}{*}{$\begin{array}{l}\text { (Conn, } \\
\text { Habteselassie, } \\
\text { Blackwood, \& } \\
\text { Noble, 2012) }\end{array}$} \\
\hline & MS2qrev & $\begin{array}{l}\text { TTCGACATGGGTAATCCTCA } \\
\text { 6-FAM- }\end{array}$ & 1758 & \\
\hline & MS2qProbe & $\begin{array}{l}\text { ATTCCCTCAGCAATCGCAGCAAACT- } \\
\text { BHQ1 }\end{array}$ & 1689 & \\
\hline \multirow[t]{3}{*}{ Tulane virus } & FW & GAGATTGGTGTCAAAACACTCTTTG & 3645 & \multirow{3}{*}{$\begin{array}{l}\text { (Sestak et al., } \\
\text { 2012) }\end{array}$} \\
\hline & RV & ATCCAGTGGCACACACAATTT & 3800 & \\
\hline & Probe & $\begin{array}{l}\text { 6-FAM-AGTTGATTGACCTGCTGTGTCA- } \\
\text { BHQ1 }\end{array}$ & 3697 & \\
\hline
\end{tabular}


${ }_{5}^{4} 371$ Table 3. Losses of MNV-1, MS2, and Tulane during elution and PEG precipitation (in $\log _{10}$ 6

7372 PFU for MNV-1 and MS2 and $\log _{10}$ TCID 50 for Tulane).

8

\begin{tabular}{lllccccc}
\hline Processing Step & Virus & \multicolumn{3}{c}{ Ham } & \multicolumn{3}{c}{ Lettuce } \\
& & N & Mean & Std Dev & N & Mean & Std Dev \\
\hline Elution & MNV-1 & 3 & ND & ND & 5 & ND & ND \\
& MS2 & 3 & 0.0 & 0.0 & 5 & 0.2 & 0.2 \\
PEG & Tulane & 3 & 2.0 & 1.8 & 5 & 3.2 & 0.2 \\
& MNV-1 & 4 & 0.3 & 0.0 & 4 & 0.3 & 0.0 \\
& MS2 & 4 & 0.1 & 0.2 & 4 & 0.1 & 0.2 \\
& Tulane & 4 & 2.7 & 0.7 & 3 & 1.0 & 1.7 \\
\hline
\end{tabular}


Baert, L., Uyttendaele, M., \& Debevere, J. (2008). Evaluation of viral extraction methods on a broad range of Ready-To-Eat foods with conventional and real-time RT-PCR for Norovirus GII detection. International Journal of Food Microbiology, 123(1-2), 101-108. http://doi.org/10.1016/j.ijfoodmicro.2007.12.020

Conn, K. E., Habteselassie, M. Y., Blackwood, A., \& Noble, R. T. (2012). Microbial water quality before and after the repair of a failing onsite wastewater treatment system adjacent to coastal waters. Journal of Applied Microbiology, 112(1), 214-224. http://doi.org/10.1111/j.1365-2672.2011.05183.x

Costafreda, M. I., Bosch, A., \& Pinto, R. M. (2006). Development, Evaluation, and Standardization of a Real-Time TaqMan Reverse Transcription-PCR Assay for Quantification of Hepatitis A Virus in Clinical and Shellfish Samples. Applied and Environmental Microbiology, 72(6), 3846-3855. http://doi.org/10.1128/AEM.0266005

Coudray, C., Merle, G., Martin-Latil, S., Guillier, L., \& Perelle, S. (2013). Comparison of two extraction methods for the detection of hepatitis A virus in lettuces using the murine norovirus as a process control. Journal of Virological Methods, 193(1), 96-102. http://doi.org/10.1016/j.jviromet.2013.05.003

Cromeans, T., Park, G. W., Costantini, V., Lee, D., Wang, Q., Farkas, T., et al. (2014).

Comprehensive Comparison of Cultivable Norovirus Surrogates in Response to Different Inactivation and Disinfection Treatments. Applied and Environmental Microbiology, AEM.01532-14. http://doi.org/10.1128/AEM.01532-14

da Silva, A. K., Le Saux, J.-C., Parnaudeau, S., Pommepuy, M., Elimelech, M., \& Le Guyader, F. 
S. (2007). Evaluation of removal of noroviruses during wastewater treatment, using real-time reverse transcription-PCR: different behaviors of genogroups I and II. Applied and Environmental Microbiology, 73(24), 7891-7897. http://doi.org/10.1128/AEM.01428-07

Farkas, T., Sestak, K., Wei, C., \& Jiang, X. (2008). Characterization of a rhesus monkey calicivirus representing a new genus of Caliciviridae. Journal of Virology, 82(11), 54085416. http://doi.org/10.1128/JVI.00070-08

Fraisse, A., Temmam, S., Deboosere, N., Guillier, L., Delobel, A., Maris, P., et al. (2011).

Comparison of chlorine and peroxyacetic-based disinfectant to inactivate Feline calicivirus, Murine norovirus and Hepatitis A virus on lettuce. International Journal of Food Microbiology, 151(1), 98-104. http://doi.org/10.1016/j.ijfoodmicro.2011.08.011

Gentry-Shields, J., \& Stewart, J. R. (2013). Similar concentration and extraction recoveries allow for use of turnip crinkle virus as a process control for enteroviruses in water. Journal of Virological Methods, 189(2), 250-257.

http://doi.org/10.1016/j.jviromet.2013.02.013

Glass, R. I., Parashar, U. D., \& Estes, M. K. (2009). Norovirus gastroenteritis. The New England Journal of Medicine, 361(18), 1776-1785. http://doi.org/10.1056/NEJMra0804575

Gregory, J. B., Webster, L. F., Griffith, J. F., \& Stewart, J. R. (2011). Improved detection and quantitation of norovirus from water. Journal of Virological Methods, 172(1-2), 38-45. http://doi.org/10.1016/j.jviromet.2010.12.011

Griffin, S. M., Brinkman, N. E., Hedrick, E. J., Rhodes, E. R., \& Fout, G. S. (2014). Comparison of nucleic acid extraction and reverse transcription-qPCR approaches for detection of 
GI and GII noroviruses in drinking water. Journal of Virological Methods, 199, 76-85. http://doi.org/10.1016/j.jviromet.2014.01.005

Hata, A., Katayama, H., Kitajima, M., Visvanathan, C., Nol, C., \& Furumai, H. (2011). Validation of internal controls for extraction and amplification of nucleic acids from enteric viruses in water samples. Applied and Environmental Microbiology, 77(13), 4336-4343. http://doi.org/10.1128/AEM.00077-11

Jothikumar, N., Lowther, J. A., HENSHILWOOD, K., LEES, D. N., Hill, V. R., \& Vinjé, J. (2005). Rapid and sensitive detection of noroviruses by using TaqMan-based one-step reverse transcription-PCR assays and application to naturally contaminated shellfish samples. Applied and Environmental Microbiology, 71(4), 1870-1875. http://doi.org/10.1128/AEM.71.4.1870-1875.2005

Kageyama, T., Kojima, S., Shinohara, M., Uchida, K., Fukushi, S., Hoshino, F. B., et al. (2003). Broadly Reactive and Highly Sensitive Assay for Norwalk-Like Viruses Based on RealTime Quantitative Reverse Transcription-PCR. Journal of Clinical Microbiology, 41(4), 1548-1557. http://doi.org/10.1128/JCM.41.4.1548-1557.2003

Knight, A., Li, D., Uyttendaele, M., \& Jaykus, L.-A. (2013). A critical review of methods for detecting human noroviruses and predicting their infectivity. Critical Reviews in Microbiology, 39(3), 295-309. http://doi.org/10.3109/1040841X.2012.709820

Le Guyader, F. S., Parnaudeau, S., Schaeffer, J., Bosch, A., Loisy, F., Pommepuy, M., \& Atmar, R. L. (2009). Detection and quantification of noroviruses in shellfish. Applied and Environmental Microbiology, 75(3), 618-624. http://doi.org/10.1128/AEM.01507-08 Lee, S.-G., Lee, S.-H., Park, S.-W., Suh, C.-I., Jheong, W.-H., Oh, S., \& Paik, S.-Y. (2011). Standardized positive controls for detection of norovirus by reverse transcription PCR. 
Virology Journal, 8(1), 260. http://doi.org/10.1186/1743-422X-8-260

Li, D., Baert, L., Xia, M., Zhong, W., Van Coillie, E., Jiang, X., \& Uyttendaele, M. (2012).

Evaluation of methods measuring the capsid integrity and/or functions of noroviruses by heat inactivation. Journal of Virological Methods, 181(1), 1-5. http://doi.org/10.1016/j.jviromet.2012.01.001

Liu, P., Escudero, B., Jaykus, L.-A., Montes, J., Goulter, R. M., Lichtenstein, M., et al. (2013). Laboratory evidence of norwalk virus contamination on the hands of infected individuals. Applied and Environmental Microbiology, 79(24), 7875-7881. http://doi.org/10.1128/AEM.02576-13

Martin-Latil, S., Hennechart-Collette, C., Guillier, L., \& Perelle, S. (2012). Duplex RT-qPCR for the detection of hepatitis E virus in water, using a process control. International Journal of Food Microbiology, 157(2), 167-173.

http://doi.org/doi:10.1016/j.ijfoodmicro.2012.05.001

Microbiology of food and animal feed - Horizontal method for determination of hepatitis A virus and norovirus in food using real-time RT-PCR - Part 1: Method for quantification. (2013, April 18). Microbiology of food and animal feed - Horizontal method for determination of hepatitis A virus and norovirus in food using real-time RT-PCR - Part 1: Method for quantification. Geneva, Switzerland: ISO.

Mormann, S., Dabisch, M., \& Becker, B. (2010). Effects of technological processes on the tenacity and inactivation of norovirus genogroup II in experimentally contaminated foods. Applied and Environmental Microbiology, 76(2), 536-545. http://doi.org/10.1128/AEM.01797-09

Park, H., Kim, M., \& Ko, G. (2010). Evaluation of various methods for recovering human 
norovirus and murine norovirus from vegetables and ham. Journal of Food Protection, 73(9), 1651-1657.

Pintó, R. M., Costafreda, M. I., \& Bosch, A. (2009). Risk assessment in shellfish-borne outbreaks of hepatitis A. Applied and Environmental Microbiology, 75(23), 7350-7355. http://doi.org/10.1128/AEM.01177-09

Scallan, E., Hoekstra, R. M., Angulo, F. J., Tauxe, R. V., Widdowson, M.-A., Roy, S. L., et al. (2011). Foodborne illness acquired in the United States--major pathogens. Emerging Infectious Diseases, 17(1), 7-15. http://doi.org/10.3201/eid1701.091101p1

Sestak, K., Feely, S., Fey, B., Dufour, J., Hargitt, E., Alvarez, X., et al. (2012). Experimental Inoculation of Juvenile Rhesus Macaques with Primate Enteric Caliciviruses. PLoS ONE, 7(5), e37973. http://doi.org/10.1371/journal.pone.0037973.s002

Stals, A., Baert, L., Botteldoorn, N., Werbrouck, H., Herman, L., Uyttendaele, M., \& Van Coillie, E. (2009). Multiplex real-time RT-PCR for simultaneous detection of GI/GII noroviruses and murine norovirus 1. Journal of Virological Methods, 161(2), 247-253.

Stals, A., Baert, L., De Keuckelaere, A., Van Coillie, E., \& Uyttendaele, M. (2011). Evaluation of a norovirus detection methodology for ready-to-eat foods. International Journal of Food Microbiology, 145(2-3), 420-425. http://doi.org/10.1016/j.ijfoodmicro.2011.01.013

Summa, M., Bonsdorff, von, C.-H., \& Maunula, L. (2012). Evaluation of four virus recovery methods for detecting noroviruses on fresh lettuce, sliced ham, and frozen raspberries. Journal of Virological Methods, 183(2), 154-160.

http://doi.org/10.1016/j.jviromet.2012.04.006

Topping, J. R., Schnerr, H., Haines, J., Scott, M., Carter, M. J., Willcocks, M. M., et al. (2009). Temperature inactivation of Feline calicivirus vaccine strain FCV F-9 in comparison 
3

with human noroviruses using an RNA exposure assay and reverse transcribed quantitative real-time polymerase chain reaction-A novel method for predicting virus infectivity. Journal of Virological Methods, 156(1-2), 89-95.

http://doi.org/10.1016/j.jviromet.2008.10.024

493 Tung, G., Macinga, D., Arbogast, J., \& Jaykus, L.-A. (2013). Efficacy of commonly used disinfectants for inactivation of human noroviruses and their surrogates. Journal of Food Protection, 76(7), 1210-1217. http://doi.org/10.4315/0362-028X.JFP-12-532

USEPA. (2001). Method 1602: Male-specifc (F+) and Somatic Coliphage in Water - April 2001 version, $1-38$. 


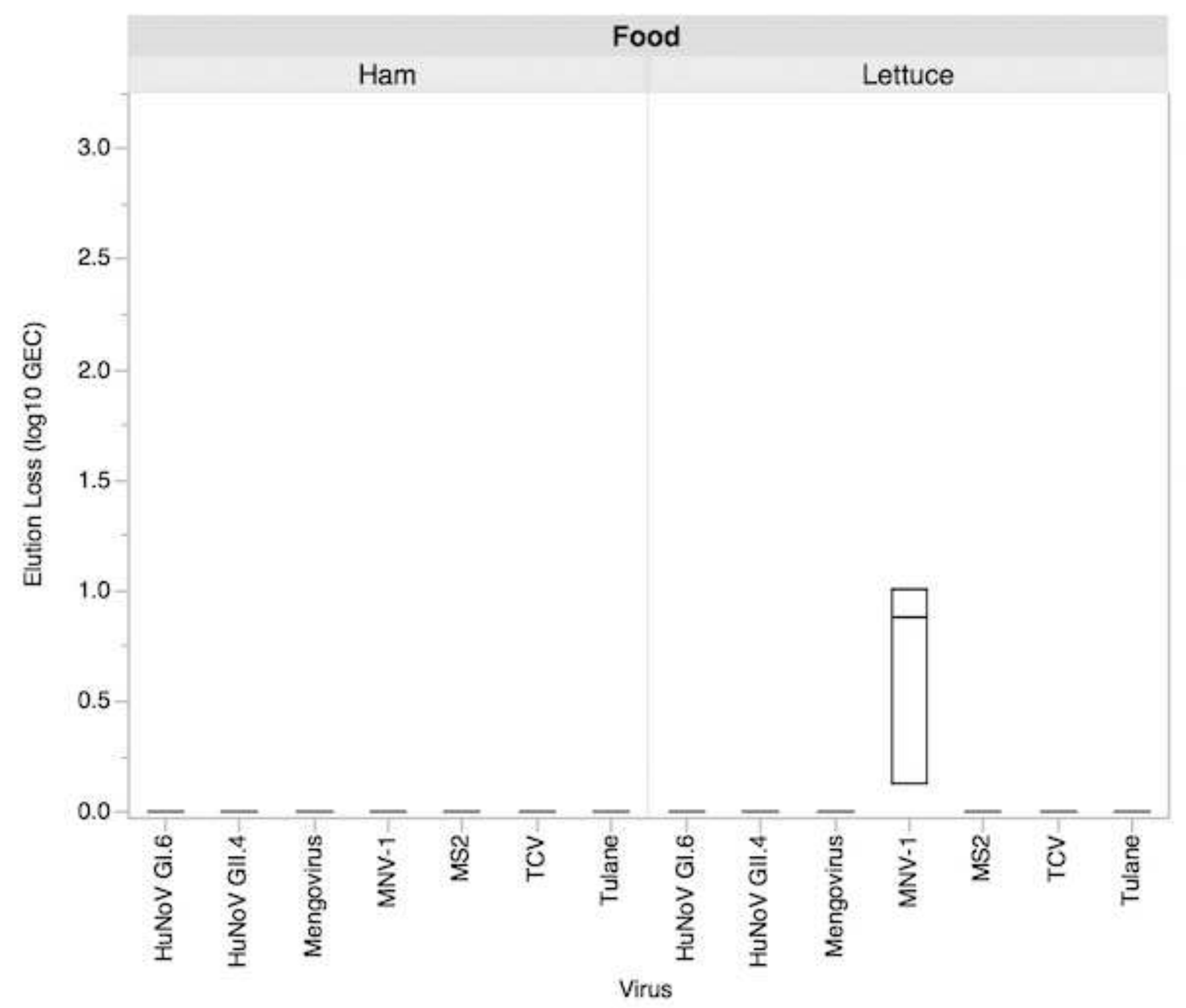




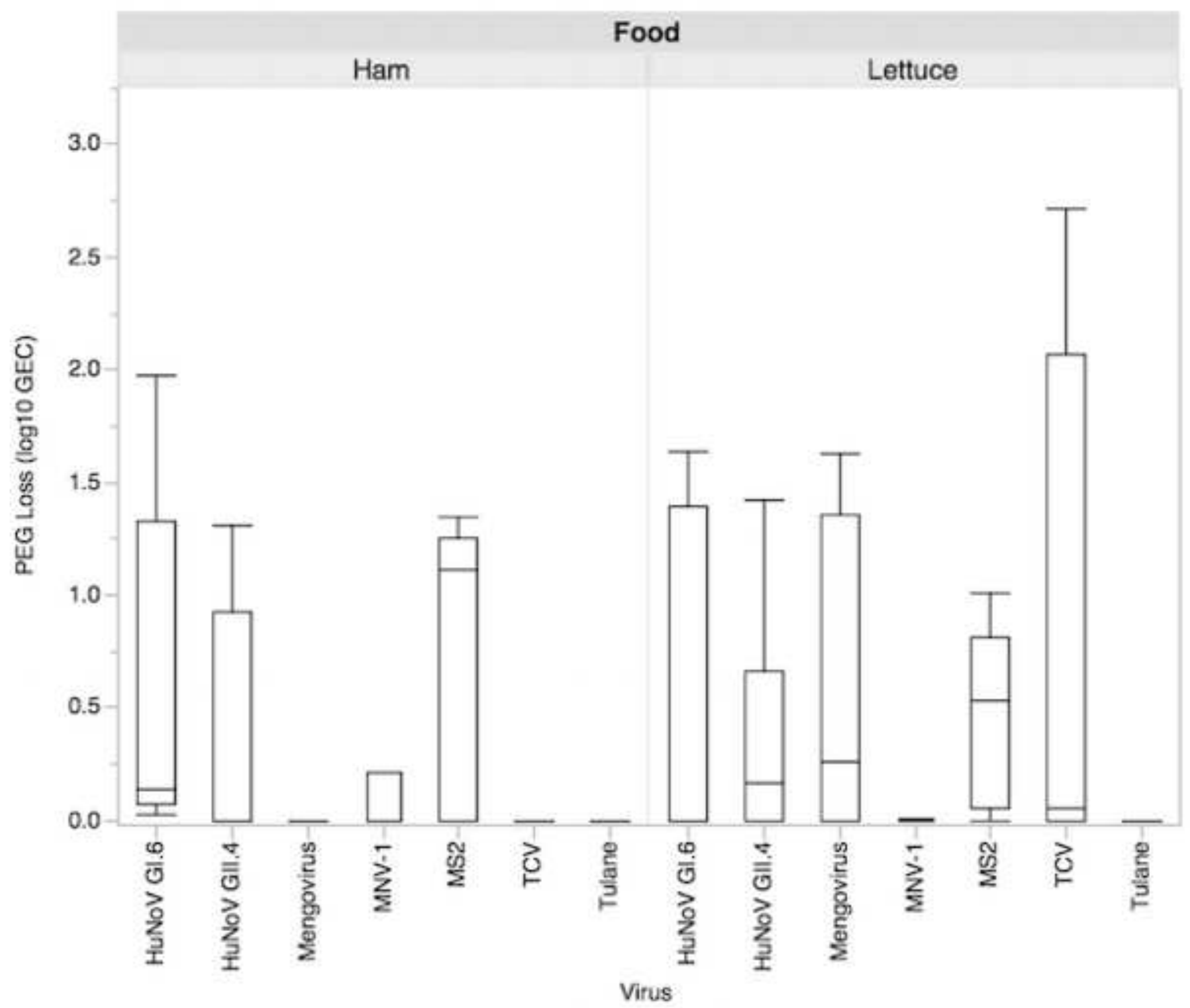




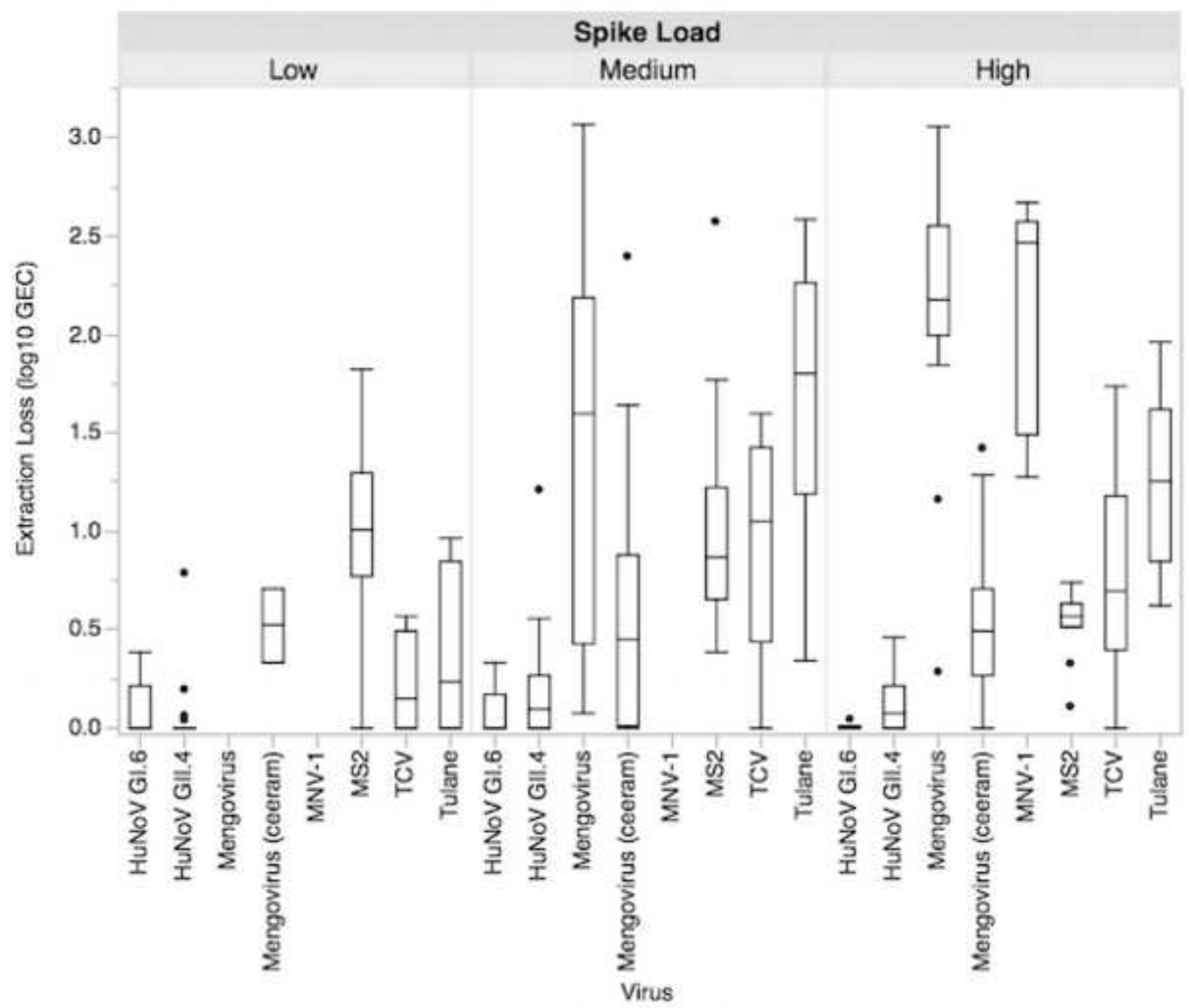

